\title{
Fracture Properties of Nash Point Limestone and Implications for Fracturing of Layered Carbonate Sequences
}

\author{
Nathaniel D. Forbes Inskip ${ }^{1}$ (D) Philip G. Meredith ${ }^{2}$
}

Received: 18 July 2020 / Accepted: 9 February 2021 / Published online: 3 March 2021

(c) The Author(s) 2021

\begin{abstract}
Carbonate reservoirs accommodate a significant proportion of global hydrocarbon reserves. However they are often tight and permeability is therefore usually dependent on either flow through existing fractures or through those produced by hydraulic stimulation. Hence, understanding how fracture networks develop in carbonate reservoir rocks is key to efficient and effective production. However, despite their prevalence as reservoir rocks, there is a paucity of data on key fracture properties of carbonate rocks, particularly in more than one orientation. Here, therefore we report measurements of both the tensile strength and fracture toughness of Nash Point limestone in the three principal fracture orientations to determine what effect any mechanical anisotropy might have on fracture propagation. We find Nash Point limestone to be essentially isotropic in terms of both its microstructure and its fracture properties. When comparing the fracture toughness of Nash Point limestone with that of others limestones, we find that fracture toughness decreases with increasing porosity, although this dependency is not as strong as found in other porous rocks. Finally, as many so-called carbonate reservoirs actually comprise layered sequences, we extend our analysis to consider the layered sequence of limestones and shales at Nash Point. We find that the fracture toughness of Nash Point limestone is higher than Nash Point shale but that the fracture energy is lower. We therefore discuss how the implications of fracturing through multi-layered sequences could be explored in future work.
\end{abstract}

Keywords Fracture mechanics $\cdot$ Limestone $\cdot$ Mechanical stratigraphy

\section{Introduction}

A significant proportion of global hydrocarbon reserves are hosted within carbonate reservoirs, including limestones (Lamarche et al. 2012; Burberry and Peppers 2017; Li et al. 2018). Limestones are usually considered brittle and are therefore likely to have higher Young's moduli than other sedimentary rocks in a basin (Afşar et al. 2014). As such, limestones can often become fractured following deposition and burial, thereby enhancing their porosity and permeability (Dashti et al. 2018; Li et al. 2018). By contrast, where limestones are not naturally fractured and the matrix permeability is low, hydraulic stimulation or hydraulic fracturing is commonly required to enhance permeability and increase

Nathaniel D. Forbes Inskip

n.forbes_inskip@hw.ac.uk

1 The Lyell Centre, Institute of Geoenergy Engineering, Heriot-Watt University, Edinburgh, UK

2 Department of Earth Sciences, University College London, London, UK fluid flow. Examples of limestone reservoirs which are considered tight include the Taq Taq, Kirkuk, Jambur, Khabaz and Bai Hassan oil fields in the Zagros fold belt (Rashid et al. 2017) and the Dariyan formation in the central Persian Gulf (Hosseini et al. 2018). In both situations, it is important to know the fracture properties of the limestone, firstly to determine fracture spacing, aperture and tortuosity, and thus accurately estimate reservoir porosity and permeability, and secondly to understand how and when fractures will propagate during anthropogenic stimulation.

Despite its prevalence as a reservoir rock, relatively few studies have been conducted on the tensile fracture properties of limestones, especially where both tensile strength and fracture toughness have been measured in more than one orientation to address the issue of anisotropy. In Table 1, we summarise the available data on tensile strength and mode-I fracture toughness $\left(K_{\mathrm{Ic}}\right)$ of different limestones. The data clearly show that limestone mechanical properties vary over a wide range, with tensile strengths varying from 2.3 to $15 \mathrm{MPa}$, and values of $K_{\mathrm{Ic}}$ varying from 0.24 to $2.06 \mathrm{MPa} \mathrm{m}{ }^{1 / 2}$. For many of the studies listed in Table 1, 
Table 1 Fracture properties of a variety of limestones

\begin{tabular}{|c|c|c|c|c|c|}
\hline Rocktype & Orientation & Tensile strength (MPa) & $K_{\text {Ic }}\left[\right.$ method $\left(\mathrm{MPa} \mathrm{m}^{1 / 2}\right)$ & Porosity & References \\
\hline Indiana limestone & Short-transverse & - & $0.71[\mathrm{SCN}-3]$ & $10-15 \%$ & Schmidt (1976) \\
\hline Indiana limestone & Arrester/Divider & 5.38 & $0.85-0.89[\mathrm{SCN}-3]$ & $10-15 \%$ & Schmidt (1976) \\
\hline Irondequoit limestone & Normal to bedding & 11.9 & $1.36[\mathrm{SR}]$ & 3 & Gunsallus and Kulhawy (1984) \\
\hline Reynales limestones & Normal to bedding & 15 & $2.06[\mathrm{SR}]$ & 0.7 & Gunsallus and Kulhawy (1984) \\
\hline Solnhofen limestone & Normal to bedding & - & $1.01[\mathrm{DT}]$ & - & Atkinson (1984) \\
\hline Solnhofen limestone & Parallel to bedding & - & $0.87[\mathrm{DT}]$ & - & Atkinson (1984) \\
\hline Pierre de Lens & $?$ & - & $\begin{array}{l}0.62[\mathrm{CCCD}] \\
0.64[\mathrm{SCB}] \\
0.68[\mathrm{CCNBD}]\end{array}$ & $13 \%$ & Helmer et al. (2014) \\
\hline Guiting limestone & $?$ & - & $\begin{array}{l}0.24[\mathrm{CCCD}] \\
0.35[\mathrm{SCB}]\end{array}$ & Porous & Aliha et al. (2012) \\
\hline Limestone (Saudi Arabia) & $?$ & 2.31 & $\begin{array}{l}0.35-0.42[\mathrm{CCCD}] \\
0.61[\mathrm{CCNBD}]\end{array}$ & $5.4 \%$ & Khan and Al-Shayea (2000) \\
\hline Oolitic limestone (SE Spain) & $?$ & $7.8 \pm 1.1$ & $0.72[\mathrm{SCN}-4]$ & - & Cicero et al. (2014) \\
\hline Treuchtlinger Marmor & $?$ & $8.2 \pm 2.2$ & $\sim 1.3[\mathrm{CB}]$ & - & Stoeckhert et al. (2016) \\
\hline Jurassic limestone & $?$ & - & $1.04[\mathrm{SCN}-3]$ & - & Dibb et al. (1983) \\
\hline Carboniferous limestone & $?$ & - & $1.25[\mathrm{SCN}-3]$ & - & Dibb et al. (1983) \\
\hline White limestone & $?$ & - & $1.65[\mathrm{CB}]$ & - & Guo et al. (1993) \\
\hline Grey limestone & $?$ & - & $1.42[\mathrm{CB}]$ & - & Guo et al. (1993) \\
\hline Welsh limestone & $?$ & $8.49 \pm 0.86$ & $0.85[\mathrm{SCB}]$ & - & Nath Singh and Sun (1990) \\
\hline Balmholtz limestone & $?$ & - & $1.77[\mathrm{CB}]$ & - & Bergkvist and Fornerod (1979) \\
\hline Hällekis limestone & $?$ & - & $1.25[\mathrm{SCN}-4]$ & - & Lundborg and Almgren (1972) \\
\hline Shelly limestone & $?$ & - & $1.44[\mathrm{SR}]$ & - & Meredith (1989) \\
\hline Klinthagen limestone & $?$ & - & $1.31[\mathrm{CB}]$ & - & Ouchterlony and Sun (1983) \\
\hline
\end{tabular}

Abbreviations for the different methods are: $S C N-3$ straight cut notched sample in three point bending, $S C N-4$ straight cut notched sample in four point bending, $S R$ short-rod, $D T$ double torsion, $C C C D$ centre cracked circular disk, $S C B$ semi-circular bend, $C C N B D$ cracked chevron notched Brazilian disk, $C B$ chevron bend

information on testing orientation and other rock properties is unfortunately missing, but any additional information available on the methods and materials is provided in the Supporting Information.

Given the importance of limestone fracture properties, and their variation with orientation to bedding, we report results from a systematic study where we measured both the tensile strength and mode-I fracture toughness $\left(K_{\mathrm{Ic}}\right)$ of Nash Point limestone in all three principal fracture orientations (Short-transverse, Arrester and Divider (Chong et al. 1987), which are defined in the methodology and described in the Supplementary Information).

\section{Sample Material and Characterisation}

\subsection{Mineralogy and Microstructure}

Nash Point limestone is the limestone member of the Porthkerry Formation, which comprises a repeating sequence of limestone and shale strata outcropping at Nash
Point on the northern shore of the Bristol Channel in south Wales, UK (Fig. 1).

Thin section analysis demonstrates that Nash Point limestone is poorly sorted, with grains that are angular to sub-angular but with no significant alignment (Fig. 2). The majority of the grains are shell fragments, such as bivalve, gastropod, echinoderm and sponge spicules. The nature of the grain angularity and the proportion of shell fragments present suggest that the environment of deposition was low energy and likely shallow marine. The shell fragments range in size up to $3 \mathrm{~mm}$. XRD analysis shows that Nash Point limestone is comprised predominately of calcite $(>90 \%)$, with lesser amounts of quartz (5-7\%), clays and other trace minerals $(<3 \%)$.

The Nash Point limestone used in this study had a bulk density of $2671 \mathrm{~kg} \mathrm{~m}^{-3}$ and a porosity of $\sim 1 \%$, measured using Helium pycnometry (Heap et al. 2009; Chandler et al. 2016; Chalmers and Bustin 2017), very similar to the porosity of 0.82 to $1.52 \%$ reported by Afşar et al. (2014) for limestone from three locations around the Bristol Channel. The bulk density is very close to that of pure calcite 

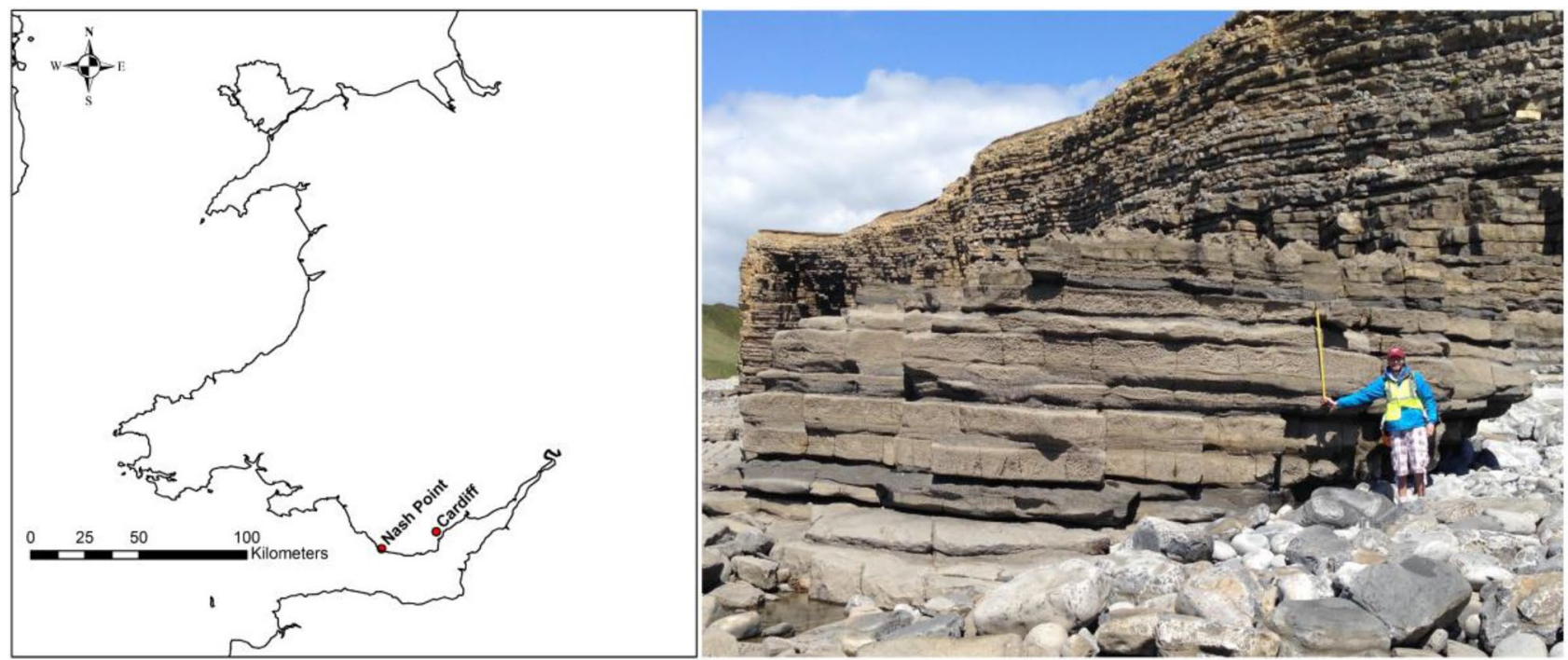

Fig. 1 Left - Map of Wales showing the location of Nash Point on the north coast of the Bristol Channel. Right - Cliff section at Nash Point showing the inter-bedded sequence of limestone and shaly mudstone.

Cliff height in the background is approximately $30 \mathrm{~m}$. Modified after Forbes Inskip et al. (2018)

Fig. 2 Thin section of Nash Point limestone with $1 \mathrm{~mm}$ bars for scale. This is a vertical section through a horizontal bed

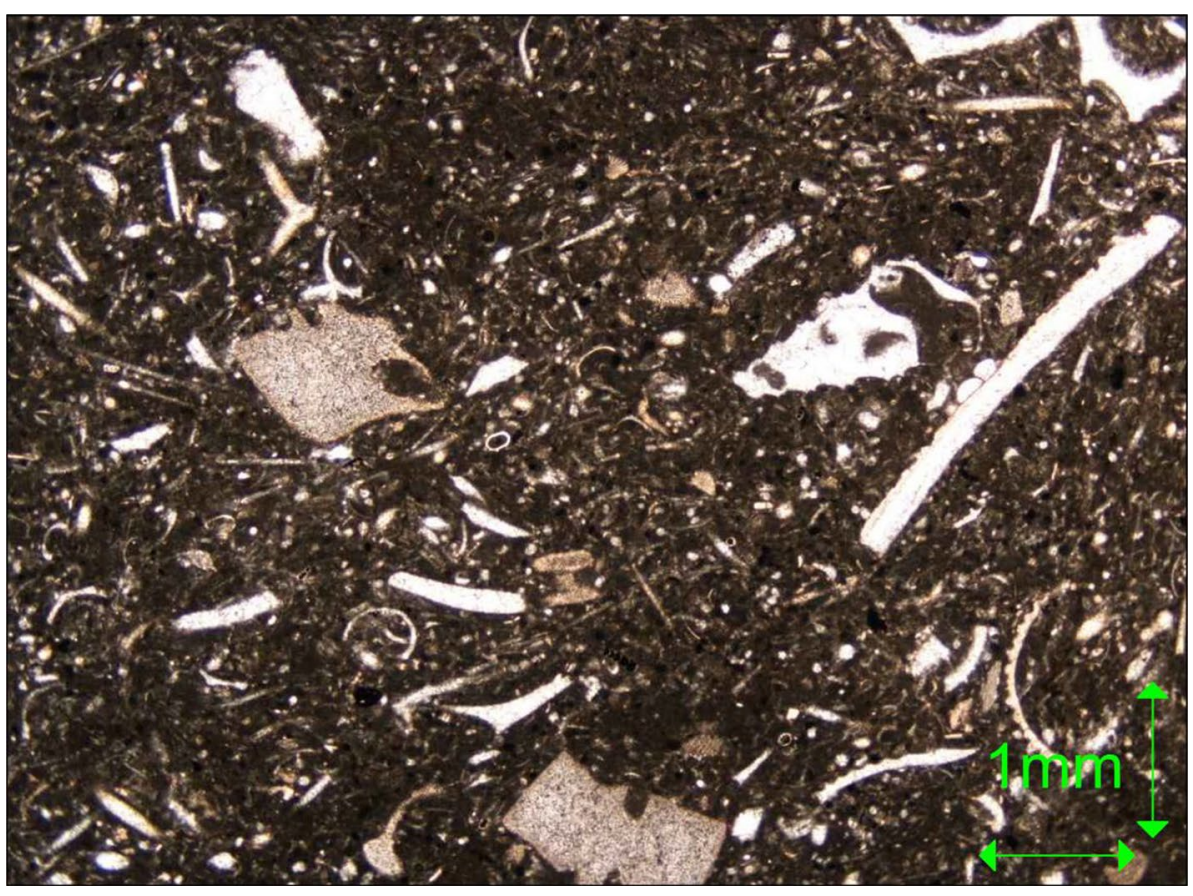

$\left(2710 \mathrm{~kg} \mathrm{~m}^{-3}\right)$, which is not surprising given the XRD analysis and the very low porosity.

\subsection{Elastic Anisotropy and Moduli}

We characterised the anisotropy of Nash point limestone by measuring the $\mathrm{P}$-wave and $\mathrm{S}$-wave velocities of $38 \mathrm{~mm}$ cylindrical samples under dry, ambient pressure and ambient temperature conditions. Velocities were measured both parallel and normal to bedding on multiple samples.
The mean P-wave velocity parallel to bedding $\left(V_{p 0}\right)$ was $5.88 \pm 0.03 \mathrm{~km} \mathrm{~s}^{-1}$, and that normal to bedding $\left(V_{p 90}\right)$ was $5.79 \pm 0.02 \mathrm{~km} \mathrm{~s}^{-1}$, giving a P-wave velocity anisotropy of $<2 \%$.

For comparison, the S-wave velocity parallel to bedding $\left(V_{s H 0}\right)$ was $3.50 \pm 0.03 \mathrm{~km} \mathrm{~s}^{-1}$ and that normal to bedding $\left(V_{s H 90}\right)$ was $3.48 \pm 0.02 \mathrm{~km} \mathrm{~s}^{-1}$, giving an $\mathrm{S}$-wave velocity anisotropy of $<1 \%$. Given that these differences in velocity are within the picking accuracy of first arrivals for both P and S waves (Vinciguerra et al. 2005), Nash 
Point limestone can be considered essentially elastically isotropic. Using these values and standard relationships (Wang 2002; Mavko et al. 2009), we calculate the dynamic Young's modulus of Nash Point limestone to be $76.9 \mathrm{GPa}$ normal to bedding and $79.9 \mathrm{GPa}$ parallel to bedding, and the three dynamic Poisson's ratio's, $\nu_{31}, \nu_{13}$ and $\nu_{12}$, to be $0.23,0.24$ and 0.22 , respectively.

We also measured the static (tangent) Young's moduli and Poisson's ratios using conventional uniaxial compression tests (ISRM 1970) on cores loaded parallel and normal to bedding. The static Young's modulus parallel to bedding was $26.3 \mathrm{GPa}$ and that normal to bedding was $28.5 \mathrm{GPa}$, and the static Poisson's ratio was found to be 0.14 for both orientations. All of these data are summarised in Table 2, and examples of representative stress-strain curves are provided in the Supporting Information. We note that our static Young's modulus values are lower than the values of 38-48 GPa reported by Afşar et al. (2014) for other limestone samples from the Bristol Channel. However, Afşar et al. (2014) sampled material from three different sites along the Bristol Channel, but do not indicate from which site their Young's modulus samples were collected.

\subsection{Methods}

In this study, we measured tensile strength using the Brazil disk test (ISRM 1978) and mode-I fracture toughness $\left(K_{\mathrm{Ic}}\right)$ using both the Semi-circular Bend (Kuruppu et al. 2014) and short-rod (ISRM 1988) testing methods. These are all Suggested Methods recommended by the International Society of Rock Mechanics (ISRM). For each suite of tests, measurements were made in all three principal fracture orientations: Short-transverse (where both the fracture plane and the fracture propagation direction are parallel to bedding), Arrester (where both the fracture plane and the fracture propagation direction are normal to bedding), and Divider (where the fracture plane is normal to bedding but the fracture propagation direction is parallel to bedding) (Chong et al. 1987).

\subsection{Tensile Strength}

We measured the indirect tensile strength of Nash Point limestone using Brazil disk samples measuring $38 \mathrm{~mm}$ in diameter by $19 \mathrm{~mm}$ in thickness. Sample preparation and testing were carried out using the same facilities, jigs and fixtures as described in Forbes Inskip et al. (2018). Samples were cored from a single block of material gathered from Nash Point, and their surfaces ground flat and parallel to within $0.02 \mathrm{~mm}$ using a surface grinder. All samples were loaded diametrically, at a constant displacement rate of $0.1 \mathrm{~mm} \mathrm{~min}{ }^{-1}$ using a Brazil test jig mounted within a servo-controlled loading frame. A minimum of four tests were carried out in each orientation.

\subsection{Fracture Toughness}

Mode-I fracture toughness $\left(K_{\mathrm{Ic}}\right)$ was measured using both the Semi-circular Bend (SCB) (Kuruppu et al. 2014) and short-rod (SR) (ISRM 1988) test methodologies. Sample preparation and testing were carried out using the same facilities, jigs and fixtures as described in Forbes Inskip et al. (2018) and Chandler et al. (2016). Therefore, we only provide a brief description here, and refer the reader to the above studies and the relevant ISRM Suggested Methods for more detailed descriptions. All of our SCB and SR samples were cored from the same block of material as the Brazil disk samples.

SCB samples were manufactured from $76 \mathrm{~mm}$ diameter cores, cut to a thickness of $30 \mathrm{~mm}$. The faces of each disk were ground flat and parallel to eachother to within $0.02 \mathrm{~mm}$ using a surface grinder. Each disk was then cut in half to produce two quasi-semi-circular samples. The cut edge was then ground flat, before a straight notch was cut perpendicular to this surface in the centre of the sample using a diamond saw. The width of the notch was $1.5 \mathrm{~mm}$, and its notional depth was $22 \mathrm{~mm}$ (Forbes Inskip et al. 2018). Samples were then

Table 2 Measured elastic properties of Nash Point limestone

\begin{tabular}{|c|c|c|c|c|}
\hline & & Normal to bedding & & Parallel to bedding \\
\hline Static Young's modulus (GPa) & & 28.5 & & 26.3 \\
\hline Static Poisson's ratio & & 0.14 & & 0.14 \\
\hline $\mathrm{V}_{\mathrm{p}}\left(\mathrm{km} \mathrm{s}^{-1}\right)$ & & $5.79 \pm 0.02$ & & $5.88 \pm 0.03$ \\
\hline $\mathrm{V}_{\mathrm{s}}\left(\mathrm{km} \mathrm{s}^{-1}\right)$ & & $3.48 \pm 0.02$ & & $3.50 \pm 0.03$ \\
\hline \multirow[t]{2}{*}{ Dynamic Young's modulus (GPa) } & & 76.89 & & 79.89 \\
\hline & $v_{31}$ & & $v_{13}$ & $v_{12}$ \\
\hline Dynamic Poisson's ratio & 0.23 & & 0.24 & 0.22 \\
\hline
\end{tabular}


mounted in a testing jig and loaded in three-point bending via three hardened steel rollers at a constant displacement rate of $0.1 \mathrm{~mm} \mathrm{~min}^{-1}$.

SR samples were manufactured from $60 \mathrm{~mm}$ diameter cores that were cut to a length of $89 \mathrm{~mm}$, with the end surfaces ground flat and parallel using a surface grinder in the same way as described above. A $1.8 \mathrm{~mm}$ wide chevronshaped notch was then cut along the centre of the sample using a specially designed cutting jig, to leave a triangular ligament of material for testing (Chandler et al. 2016). Finally, a $25 \mathrm{~mm}$ wide by $6 \mathrm{~mm}$ deep groove was ground out of the end surface of the sample to enable to accommodate the hardened steel loading jaws. Samples were then mounted in a testing jig and a tensile load was applied across the groove, normal to the plane of the triangular ligament, causing a fracture to nucleate at the ligament tip and propagate along the ligament. Illustrations of both sample geometries are given in Fig. 4, which shows photographs of fractured SCB and SR samples after testing, together with photographs of fractured Brazil disk samples.

For both methods, the value of $K_{\mathrm{Ic}}$ is calculated from the peak load sustained by the sample and the sample dimensions, via standard equations (Forbes Inskip et al. 2018; Chandler et al. 2016), which are included in the Supporting Information.

\section{Results}

\subsection{Tensile Strength}

The tensile strengths (mean \pm one standard deviation) of samples of Nash Point limestone measured in the three principal orientations are given in Fig. 3 and Table 3. All of the tests produced fractures that were straight and passed through the centre of the sample and are therefore considered valid (see Fig. 4).

The strength values for all orientations are within approximately one standard deviation of each other, suggesting that Nash Point limestone is not only elastically isotropic but also essentially mechanically isotropic.
Fig. 3 Tensile strength and $K_{\text {Ic }}$ of Nash Point limestone in the three principal fracture orientations. Bars represent \pm 1 standard deviation

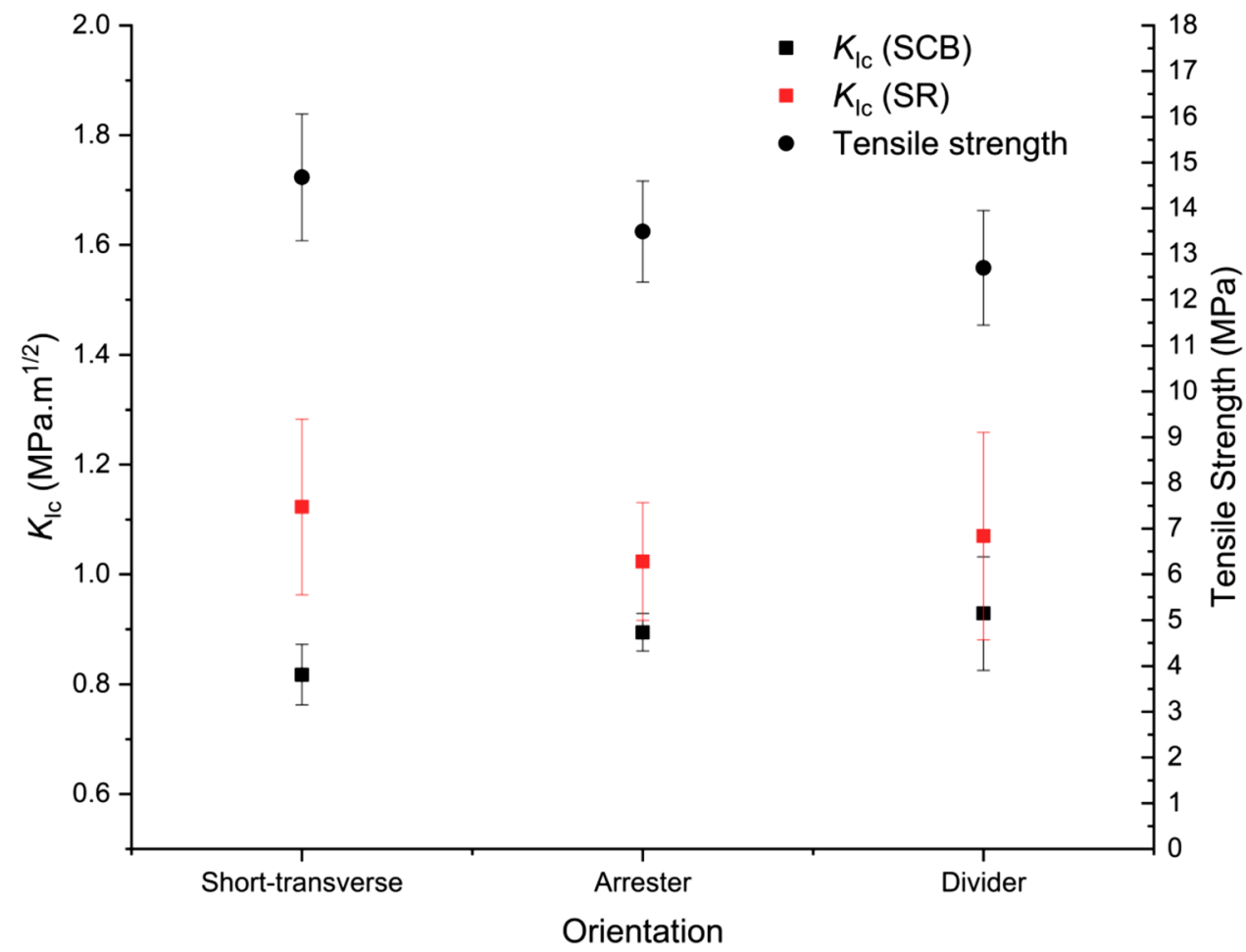

Table 3 Mean values \pm 1 standard deviation of tensile strength and $K_{\text {Ic }}$ for Nash Point limestone measured in three principal fracture orientations

\begin{tabular}{llll}
\hline & Tensile Strength $(\mathrm{MPa})$ & $K_{\mathrm{Ic}}[\mathrm{SCB}]\left(\mathrm{MPa} \mathrm{m}^{1 / 2}\right)$ & $K_{\mathrm{Ic}}[\mathrm{SR}]\left(\mathrm{MPa} \mathrm{m}^{1 / 2}\right)$ \\
\hline Short-transverse & $14.68 \pm 1.38$ & $0.82 \pm 0.05$ & $1.12 \pm 0.16$ \\
Arrester & $13.49 \pm 1.10$ & $0.89 \pm 0.03$ & $1.02 \pm 0.11$ \\
Divider & $12.70 \pm 1.25$ & $0.93 \pm 0.10$ & $1.07 \pm 0.19$ \\
\hline
\end{tabular}



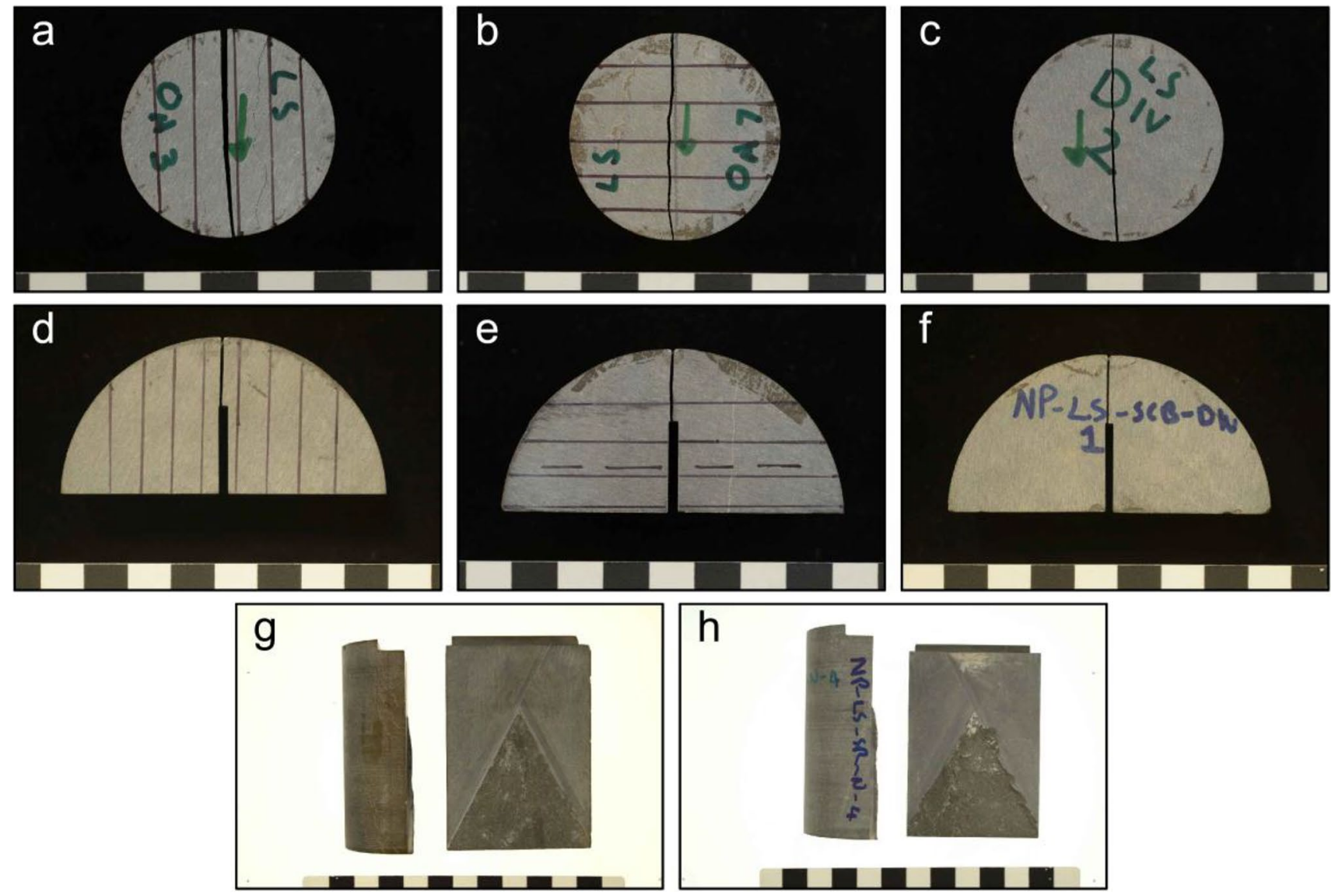

Fig. 4 Brazil disk, SCB and SR samples tested in the Short-transverse (a, $\mathbf{d}$ and $\mathbf{g})$, Arrester (b, e and $\mathbf{h})$ and Divider (c and $\mathbf{f})$ orientations. Solid black lines show the orientation of the bedding plane and a scale bar lies below each sample where each division is $1 \mathrm{~cm}$

\subsection{Fracture Toughness}

Fracture toughness results from both the SCB and SR tests are given in Table 3 and Fig. 3 where the mean \pm one standard deviation are plotted for each of the three principal orientations. All tests were considered valid for both methods as they met the necessary criterion of the fracture plane deviating by less than $5 \%$ of the sample diameter from its ideal orientation (Ingraffea et al. 1984; Kuruppu et al. 2014), as illustrated in Fig. 4.

As for the tensile strength results, we observe that the $K_{\text {Ic }}$ values for all three principal orientations fall within one standard deviation of each other for both the SCB and SR tests. Again, this supports the suggestion that Nash Point limestone is essentially isotropic. However, we also observe that the $K_{\mathrm{Ic}}$ values obtained from the SR tests are consistently higher than those from the SCB tests; by a little more than one standard deviation.

\section{Discussion}

\subsection{Influence of Orientation on Fracture Properties}

All of the data, wave velocities, tensile strengths and fracture toughnesses, indicate that Nash Point limestone is both elastically and mechanically isotropic. This is entirely consistent with the microstructural observation of a lack of any grain alignment within the rock matrix.

Although the outcrop at Nash Point is bedded (Fig. 1), there is uncertainty as to whether the origin of the limestone beds is primary and depositional or secondary and diagenetic. A diagenetic origin has been hypothesised by Sheppard et al. (2006), and the nodular nature of some of the beds may support this. If this is the case, then the beds are likely to have grown outwards in all directions from a set of nucleation points to form nodules, and we would therefore not necessarily expect to observe any structural alignment. Consequently, we would not expect to measure any significant mechanical anisotropy.

However, the majority of the rock is made up of shell fragments that are depositional in nature (Fig. 2), and their 
lack of alignment may not be entirely explained by a diagenetic model which is based on dissolution and re-precipitation. Hence, the question still remains open as to whether these limestone beds are primary or secondary in origin. Nevertheless, as we have noted, all our measurements demonstrate that there is no significant mechanical anisotropy with respect to any bedding orientation. Furthermore, the fracture propagation paths in each of the three principal fracture orientations were all essentially straight and exhibited very low tortuosity (Fig. 4). This is entirely as expected for an isotropic material. This property is also important in terms of the fluid flow potential of the formation, where fluid transport through the low tortuosity limestone fractures is likely to be very different to that through the highly tortuous fractures in the shale layers in the sequence at Nash Point (Fig. 1 and Forbes Inskip et al. 2018).

\subsection{Comparison of the Different Methods to Measure $K_{\mathrm{lc}}$}

Since $K_{\mathrm{Ic}}$ is defined as a material property, different measurement methods should, in principle, produce the same results. However, this is not the case for our SCB and SR measurements on Nash Point limestone. While there is internal consistency within each method, the mean fracture toughness for each orientation is consistently higher for the SR measurements than for the SCB measurements. Interestingly, Khan and Al-Shayea (2000) also found that there was a consistent difference between $K_{\text {Ic }}$ measurements made on the same material but using samples with straight cut notches and those with chevron notches. In their tests on limestone from Saudi Arabia, they found that $K_{\text {Ic }}$ values measured using chevron-notch CCNDB samples were close to $50 \%$ higher than values measured using straight-cut-notch CCCD samples (Table 1), in spite of the fact that the sample dimensions were identical except for the notch geometry. In our measurements on Nash Point limestone, we found that $K_{\text {Ic }}$ values measured using chevron-notch SR samples were between 15\% higher (Arrester and Divider orientations) and $35 \%$ higher (Short-transverse orientation) than values measured using straight-cut-notch SCB samples. Although not as high as the differences found by Khan and Al-Shayea (2000), they are still significant. In their measurements on Guiting limestone, Aliha et al. (2012) also found discrepancies in $K_{\text {Ic }}$ values measured using different sample geometries (CCCD and SCB) even though both sample geometries used straightcut notches (Table 1). They suggested that the observed discrepancy was due to the different sample geometries, and proposed that modified forms of the standard equations that take account of variations in the maximum tangential stress close to the crack tip might be able to reconcile the different results. By contrast, Helmer et al. (2014) obtained very consistent results in their measurements on Pierre de Lens limestone using both chevron-notch and straight-cut notch samples (Table 1). They measured $K_{\text {Ic }}$ values of $0.62,0.64$ and $0.68 \mathrm{MPa} \mathrm{m}^{1 / 2}$, using CCCD, SCB and CCNBD sample geometries, respectively.

Ultimately, all fracture mechanics methodologies for measuring $K_{\text {Ic }}$ require complex sample geometries with large, stress-concentrating notches. This results in a nonuniform stress distribution within the sample, often with very high stress gradients. It is therefore perhaps not surprising that discrepancies occur between measurements made using different sample geometries. Nevertheless, this should not occur if the stress analysis of the different samples geometries is robust, and this issue should form the basis of future research on this topic. In the meantime, we would simply urge caution in comparing fracture mechanics results obtained using different measurement methodologies.

\subsection{Comparison of the Fracture Properties of Nash Point Limestone with Those of Other Limestones}

Both the tensile strength and fracture toughness values measured for Nash Point limestone lie within the broad range reported for other limestones and presented in Table 1. From the Griffith criterion (Paterson and Wong 2005), we can write the following relationship between tensile strength $\left(\sigma_{t}\right)$ and fracture toughness $\left(K_{\mathrm{Ic}}\right)$ :

$\sigma_{t}=C \frac{K_{I c}}{\sqrt{a}}$

where, $C$ is a dimensionless geometric factor, and $a$ is a characteristic (or critical) flaw size. Previous studies have shown that a broadly linear relationship exists between tensile strength and fracture toughness for many different rock types (Gunsallus and Kulhawy 1984; Bhagat 1985; Zhang 2002; Chandler et al. 2016; Forbes Inskip et al. 2018). In Fig. 5, we illustrate this relationship for limestones.

A linear least squares fit to the data from Table 1 with the addition of the results for Nash Point limestone from this study, is found to have a gradient of $8.5 \mathrm{~m}^{-1 / 2}$ and an $R^{2}$ value of 0.93 , with a forced intercept through the origin. This follows previous practice (e.g., Chandler et al. 2016; Forbes Inskip et al. 2018), since we would expect a cohesionless material with a tensile strength of zero to also have a fracture toughness of zero. However, we note that the spread in the limestone data of Fig. 5 is broader than seen for many other rocks types (e.g., see Zhang 2002). Where the relationship between tensile strength and fracture toughness is linear, it implies that the characteristic flaw size controlling fracture nucleation does not vary between rock types. While this may be a reasonable assumption for some rock types, it is almost certainly not valid for limestones which 
Fig. 5 Relationship between tensile strength and $K_{\text {Ic }}$ for different limestone formations. The solid line is a least squares fit to the data with a forced intercept through the origin. Where more than one value is provided for the same rock, the mean value is plotted in order not to distort the regression, and the error bars represent the range of values

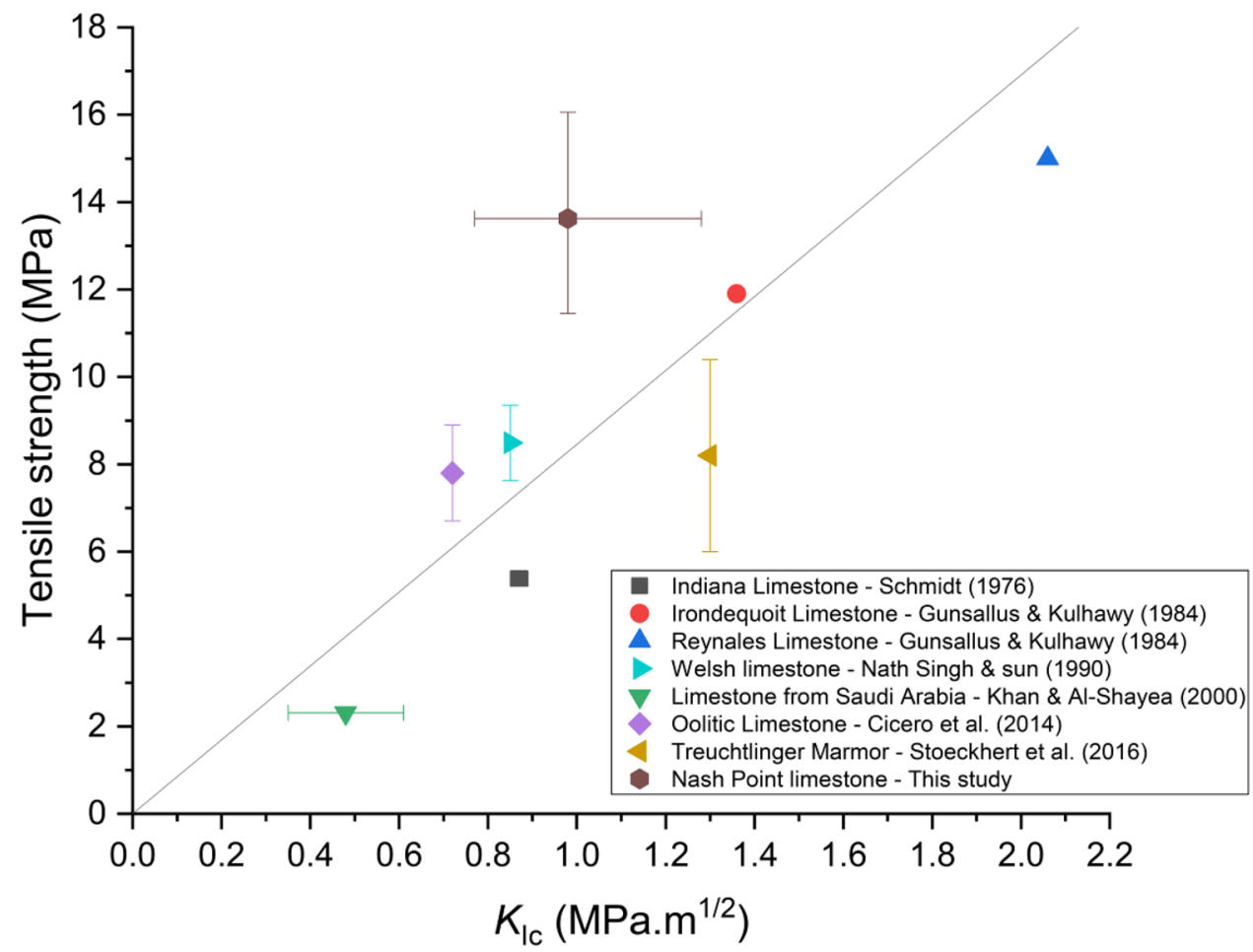

have a notoriously wide range of microstructures based on the wide variation in their diagenetic origins (Tucker 2001; Tucker and Wright 2009; Haines et al. 2016; Rashid et al. 2017). We therefore suggest that the broad spread in the data of Fig. 5 is likely due to variation in the characteristic flaw size between the different rocks. Our mean values of tensile strength $(13.62 \mathrm{MPa})$ and fracture toughness $\left(0.98 \mathrm{MPa} \mathrm{m}^{1 / 2}\right)$ fall well within the range of values listed in Table 1. However, the Nash Point limestone data sit well above the regression line and this implies that the characteristic flaw size controlling fracture nucleation in this rock is smaller than the average for the other limestones considered here. We therefore suggest that fracture nucleation in Nash Point limestone is controlled by the matrix rather than by the large shell fragments.

\subsection{Porosity}

It is a robust observation that both the strength and fracture toughness of rocks generally decrease with increasing porosity (Al-Harthi et al. 1999; Palchik and Hatzor 2004; Sabatakakis et al. 2008; Heap et al. 2009, 2014; Lian et al. 2011; Meille et al. 2012; Schaefer et al. 2015; Bubeck et al. 2016). We have therefore plotted both tensile strength and fracture toughness against porosity for the different limestones considered in this study in Fig. 6. We find a reasonable correlation between tensile strength and porosity, with an $R^{2}$ value of 0.54 . We find a weaker relationship between fracture toughness and porosity, with an $R^{2}$ value of only
0.39 (Fig. 6). This difference is perhaps not surprising. The dependence of strength on porosity is relatively straightforward. Materials with higher porosity have less solid matrix to support any applied load and therefore fail at lower stress. By contrast, fracture toughness depends on the nucleation and propagation of fractures from stress concentrating flaws (microcracks and pores). In turn, the stress intensity at the tips of such flaws depends both on the flaw size and the radius of curvature at the flaw tip. In this case, the flaw geometry takes on as much importance as the flaw density. We have already alluded to the wide range of microstructures reported for limestones (Tucker 2001; Tucker and Wright 2009; Haines et al. 2016; Rashid et al. 2017), and we therefore suggest that the poorer correlation between fracture toughness and porosity seen in Fig. 6 is likely due to the extra complexity of pore geometries and microcrack networks in carbonate rocks (Bubeck et al. 2016) relative to rocks with simpler microstructures.

\subsection{Impact on Preferential Fracture Orientation}

Our measured values of both wave velocities and fracture properties of Nash Point limestone vary very little with orientation to bedding, and we can therefore consider it to be essentially isotropic, both elastically and mechanically. Consequently, the orientation of fractures that nucleate and propagate in this rock will depend almost exclusively on external rather than internal factors, and primarily on the prevailing in-situ stress field. 
Fig. 6 Variation of $K_{\mathrm{Ic}}$ and tensile strength with Porosity of limestone data in Tables 1, 3 . Where more than one value is provided for the same rock, the mean value is plotted in order not to distort the regression

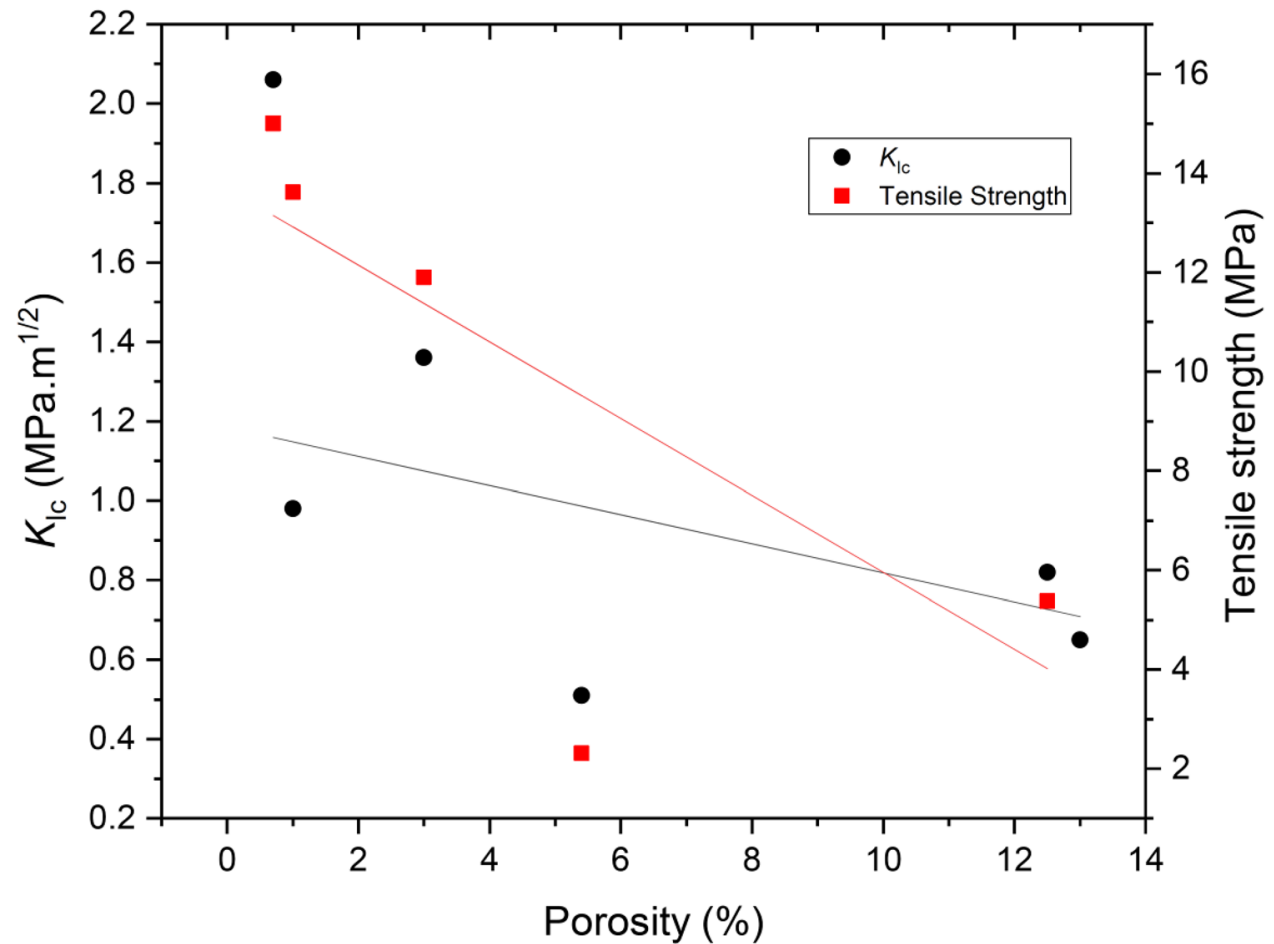

Since hydraulic fractures are by definition predominately mode-I, they will propagate parallel to the maximum principal compressive stress $\left(\sigma_{1}\right)$ and in the plane perpendicular to the minimum principal compressive stress $\left(\sigma_{3}\right)$.

The Bristol Channel Basin, which encompasses the outcrop at Nash Point, formed during the Mesozoic and has been subjected to a series of different stress regimes throughout its history that can be divided into three main components (Nemčok et al. 1995; Rawnsley et al. 1998; Peacock and Sanderson 1999; Petit et al. 2000; Belayneh and Cosgrove 2010): (1) N-S extension, which gave rise to the basin, (2) N-S compression and inversion, as a result of the Alpine Orogeny, and (3) stress relaxation following the Alpine Orogeny. The fractures shown in Fig. 1 form part of a joint set that abut against strike-slip faults related to Alpine compression, and therefore it has been suggested by Rawnsley et al. (1998) that they formed during the relaxation of compressional stresses following the Alpine Orogeny. Furthermore, data compiled from the World Stress Map project (Heidbach and Höhne 2008; Heidbach et al. 2010) for this region suggest a normal faulting regime with the maximum principal stress $\left(\sigma_{1}\right)$ being vertical and the maximum horizontal stress $\left(\sigma_{\mathrm{H}}=\sigma_{2}\right)$ being oriented NNW-SSE. As a result, and due to its isotropic nature, we would expect both natural and anthropogenic fractures to open horizontally in a WSW-ENE orientation and grow preferentially vertically at all depths in Nash Point limestone; which is what we observe in the field (Fig. 1).

\subsection{Implications for Fracture Propagation through Layered Rock Sequences}

Carbonate sequences, including that at Nash Point, are commonly composed of interbedded layers of limestone and calcareous shales (Galvis et al. 2017; Sosa et al. 2017; Forbes Inskip et al. 2018; Hosseini et al. 2018). In such sequences, there are likely significant contrasts in the fracture properties of the different strata and this will affect how fractures propagate across the sequence as a whole. For example, within the Porthkerry formation at Nash Point the Nash Point limestone is interbedded with the Nash Point shale. While the results reported here show that Nash Point limestone is essentially isotropic, previously published data (Forbes Inskip et al. 2018; Gehne et al. 2020) show that Nash Point shale is highly anisotropic, with both tensile strength and fracture toughness much lower in the Short-transverse orientation than in either of the Arrester or Divider orientations.

For a fracture propagating vertically through a horizontally layered sequence, it is the fracture toughnesses in the Arrester orientation that needs to be overcome. In this orientation, the fracture toughness of Nash Point shale is $0.74 \mathrm{MPa} \mathrm{m}^{1 / 2}$ (Forbes Inskip et al. 2018), while that of Nash Point limestone is higher at $0.89 \mathrm{MPa} \mathrm{m}^{1 / 2}$. This suggests that the resistance to dynamic fracture propagation of Nash Point limestone is higher than that of Nash Point shale in this orientation. However, outcrop measurements along the Welsh coast of the Bristol Channel show that the fracture density in the limestone can be twice as high as that in 
the shale (Hutchins 2010; Idiahi 2012) (Fig. 1). While this appears to be counterintuitive, it can be explained by taking into account the Young's modulus of each lithology which also exerts a control on the level of stress concentration. We can account for both fracture toughness and Young's modulus contrasts by calculating the critical energy release rate, or fracture energy, $\left(G_{\mathrm{c}}\right)$ of each lithology, which is given by:

$G_{c}=\frac{1-v^{2}}{E} K_{I c}^{2}$

where $E$ and $\nu$ are the values of the static Young's modulus and Poisson's ratio, respectively. Substituting the values from Tables 2, 3 into Eq. (2), we find that $G_{\mathrm{c}}$ for Nash Point limestone in the Arrester orientation is $27.6 \mathrm{~J} . \mathrm{m}^{-2}$, while that for Nash Point shale in this orientation is $177.6 \mathrm{~J} \mathrm{~m}^{-2}$ (Forbes Inskip et al. 2018); more than six times higher. Hence, considerably more energy is required to propagate a vertical fracture across the lower-toughness, but more ductile, shale than across the higher-toughness, but more brittle, limestone. This consideration is potentially important in many crustal situations involving layered sequences, such as, hydraulic stimulation in subsurface energy systems (e.g., unconventional gas and geothermal reservoirs) and dyke propagation through stratovolcano sequences leading to possible volcanic eruptions. In each case, the individual rock layers are likely to have contrasting mechanical properties, and that will affect how fractures traverse the sequence as a whole. Although, our analysis of the rocks at Nash Point helps to explain the higher fracture density observed in the limestone with respect to the shale, a full understanding of the conditions under which fractures may either propagate across multiple layers or become arrested within a single layer requires a more detailed analysis. This is beyond the scope of the current study, but is considered in Forbes Inskip et al. (2020). However, we suggest that our approach of using both fracture toughness and fracture energy in the analysis of fracture propagation across layered rock sequences should be considered in future work in this field of research.

\section{Conclusions}

We measured the tensile strength and fracture toughness of Nash Point limestone in all three principal fracture orientations and found very little difference in the values between the different orientations. We also found that the fracture propagation paths from all our mechanical tests were essentially straight for each orientation, with very little tortuosity. We therefore conclude that Nash Point limestone is essentially, mechanically isotropic.
When comparing our results with those from other studies in the literature, we find that both the tensile strength and fracture toughness values measured for Nash Point limestone fall within the broad range reported for other limestones. However, our data sit well above the best fit regression line in Fig. 5, suggesting that the characteristic flaw size for Nash Point limestone is smaller than for many other limestones and that fracture nucleation is therefore controlled by the matrix grains rather than by the large shell fragments.

Finally, given that the Porthkerry formation at Nash Point is composed of a sequence of Nash Point limestone layers interbedded with shale layers, we analyse how contrasts in fracture and elastic properties may influence vertical fractures crossing the sequence. We conclude that, although Nash Point limestone has a higher fracture toughness than Nash Point shale, it has a much lower fracture energy. Hence, more energy is required to propagate a vertical fracture across the lower-toughness shale than across the higher-toughness limestone, and this may explain the higher fracture density observed in the limestone.

Supplementary Information The online version contains supplementary material available at https://doi.org/10.1007/s00603-021-02403-4.

Acknowledgements NFI acknowledges financial support from the NERC CDT in Oil and Gas (Grant NE/M00578X/1) throughout his $\mathrm{PhD}$ at Royal Holloway, University of London. Without this support this work would not be possible. NFI would also like to thanks all those who helped collect samples from the field: Stephan Gehne, John Webb, Kathryn Lamb, Emma Davies, John Corr, Jackie Forbes Inskip, Roy Forbes Inskip, Robert Inskip, and Sally Inskip.

Open Access This article is licensed under a Creative Commons Attribution 4.0 International License, which permits use, sharing, adaptation, distribution and reproduction in any medium or format, as long as you give appropriate credit to the original author(s) and the source, provide a link to the Creative Commons licence, and indicate if changes were made. The images or other third party material in this article are included in the article's Creative Commons licence, unless indicated otherwise in a credit line to the material. If material is not included in the article's Creative Commons licence and your intended use is not permitted by statutory regulation or exceeds the permitted use, you will need to obtain permission directly from the copyright holder. To view a copy of this licence, visit http://creativecommons.org/licenses/by/4.0/.

\section{References}

Afşar F, Westphal H, Philipp SL (2014) How facies and diagenesis affect fracturing of limestone beds and reservoir permeability in limestone-marl alternations. Mar Pet Geol 57:418-432. https:// doi.org/10.1016/j.marpetgeo.2014.05.024

Al-Harthi AA, Al-Amri RM, Shehata WM (1999) The porosity and engineering properties of vesicular basalt in Saudi Arabia. Eng Geol 54:313-320. https://doi.org/10.1016/S0013-7952(99)00050 $-2$

Aliha MRM, Sistaninia M, Smith DJ, Pavier MJ, Ayatollahi MR (2012) Geometry effects and statistical analysis of mode I fracture in 
guiting limestone. Int J Rock Mech Min Sci 51:128-135. https:// doi.org/10.1016/j.ijrmms.2012.01.017

Atkinson BK (1984) Subcritical crack growth in geological materials. J Geophys Res, 4077-4114

Belayneh M, Cosgrove JW (2010) Hybrid veins from the southern margin of the Bristol Channel Basin, UK. J Struct Geol 32:192-201. https://doi.org/10.1016/j.jsg.2009.11.010

Bergkvist H, Fornerod M (1979) Fracture Toughness Measurements on Core Samples

Bhagat R (1985) Mode I fracture toughness of coal. Int J Mining Eng 3:229-236

Bubeck A, Healy D, Walker RJ, Holwell DA, Dobbs M (2016) Pore geometry as a control on rock strength. Earth Planet Sci Lett 457:38-48. https://doi.org/10.1016/j.epsl.2016.09.050

Burberry CM, Peppers MH (2017) Fracture characterization in tight carbonates: an example from the Ozark Plateau, Arkansas. AAPG Bulletin 101:1675-1696. https://doi.org/10.1306/01251715242

Chalmers GRL, Bustin RM (2017) A multidisciplinary approach in determining the maceral (kerogen type) and mineralogical composition of Upper Cretaceous Eagle Ford Formation: impact on pore development and pore size distribution. Int J Coal Geol 171:93-110. https://doi.org/10.1016/j.coal.2017.01.004

Chandler MR, Meredith PG, Brantut N, Crawford BR (2016) Fracture toughness anisotropy in shale. J Geophys Res: Solid Earth 121:1-24. https://doi.org/10.1002/2015JB012756

Chong KP, Kuruppu MD, Kuszmaul JS (1987) Fracture toughness determination of layered materials. Eng Fracture Mech 28:43-54. https://doi.org/10.1016/0013-7944(87)90118-4

Cicero S, García T, Castro J, Madrazo V, Andrés D (2014) Analysis of notch effect on the fracture behaviour of granite and limestone: an approach from the theory of critical distances. Eng Geol 177:1-9. https://doi.org/10.1016/j.enggeo.2014.05.004

Dashti R, Rahimpour-Bonab H, Zeinali M (2018) Fracture and mechanical stratigraphy in naturally fractured carbonate reservoirs-a case study from Zagros region. Mar Pet Geol 97:466-479. https://doi. org/10.1016/j.marpetgeo.2018.06.027

Dibb TE, Hughes DW, Poole AB (1983) The identification of critical factors affecting rock durability in marine environments. Q J Eng GeolHydrogeol 16:149-161. https://doi.org/10.1144/gsl. qjeg.1983.016.02.08

Forbes Inskip ND, Meredith PG, Chandler MR, Gudmundsson A (2018) Fracture properties of Nash Point shale as a function of orientation to bedding. J Geophys Res: Solid Earth. https://doi. org/10.1029/2018JB015943

Forbes Inskip ND, Browning J, Meredith PG, Gudmundsson A (2020) Conditions for fracture arrest in layered rock sequences. Results Geophys Sci 1:100001. https://doi.org/10.1016/j.ringp s.2020.100001

Galvis H, Becerra D, Slatt R (2017) Lithofacies and stratigraphy of a complete Woodford Shale outcrop section in South Central Oklahoma: geologic considerations for the evaluation of unconventional shale reservoirs. Interpretation. https://doi.org/10.1190/ int-2017-0074.1

Gehne S, Forbes Inskip ND, Benson PM, Meredith PG, Koor N (2020) Fluid-driven tensile fracture and fracture toughness in Nash point shale at elevated pressure. J Geophys Res: Solid Earth 125:1-11. https://doi.org/10.1029/2019JB018971

Gunsallus KL, Kulhawy FH (1984) A comparative evaluation of rock strength measures. Int J Rock Mech Mining Sci Geomech 21:233 248. https://doi.org/10.1016/0148-9062(84)92680-9

Guo H, Aziz NI, Schmidt LC (1993) Rock fracture-toughness determination by the Brazilian test. Eng Geol 33:177-188. https://doi. org/10.1016/0013-7952(93)90056-I

Haines TJ, Michie EAH, Neilson JE, Healy D (2016) Permeability evolution across carbonate hosted normal fault zones. Mar Pet Geol 72:62-82. https://doi.org/10.1016/j.marpetgeo.2016.01.008
Heap MJ, Vinciguerra S, Meredith PG (2009) The evolution of elastic moduli with increasing crack damage during cyclic stressing of a basalt from Mt. Etna volcano. Tectonophysics 471:153-160. https ://doi.org/10.1016/j.tecto.2008.10.004

Heap MJ, Xu T, Chen CF (2014) The influence of porosity and vesicle size on the brittle strength of volcanic rocks and magma. Bull Volcanol 76:1-15. https://doi.org/10.1007/s00445-014-0856-0

Heidbach O, Höhne J (2008) CASMI-A visualization tool for the World Stress Map database. Comput Geosci 34:783-791. https://doi. org/10.1016/j.cageo.2007.06.004

Heidbach O, Tingay M, Barth A, Reinecker J, Kurfeß D, Müller B (2010) Global crustal stress pattern based on the World Stress Map database release 2008. Tectonophysics 482:3-15. https://doi. org/10.1016/j.tecto.2009.07.023

Helmer G, Sulem J, Ghabezloo S, Rohmer J, Hild F (2014) Experimental evaluation of the fracture toughness on a limestone. Rock Eng Rock Mech: Struct Rock Masses. https://doi.org/10.1201/ b16955-34

Hosseini M, Tavakoli V, Nazemi M (2018) The effect of heterogeneity on NMR derived capillary pressure curves, case study of Dariyan tight carbonate reservoir in the central Persian Gulf. J Petrol Sci Eng 171:1113-1122. https://doi.org/10.1016/j.petrol.2018.08.054

Hutchins R (2010) Fault propagation and fracture development in the Bristol channel: implications for permeability. University of London, Royal Holloway

Idiahi E (2012) Fracture patterns and permeability in carbonate rocks: a case study St. Donats South Wales. Royal Holloway, University of London

Ingraffea A, Gunsallus K, Beech J, Nelson P (1984) A Short-rod based system for fracture toughness testing of rock. In: Underwood JH, Freiman SW, Baratta FI (eds) Chevron-notched specimens-testing and stress analysis. ASTM, Philadelphia, pp $152-166$

ISRM (1970) Suggested method for determining deformability of rock materials in uniaxial compression. 138-140

ISRM (1988) Suggested methods for determining the fracture toughness of rock. Int J Rock Mech Mining Sci Geomech Abstracts 25:71-96. https://doi.org/10.1016/S0148-9062(96)00015-0

Khan K, Al-Shayea NA (2000) Effect of specimen geometry and testing method on mixed Mode I-II fracture toughness of a limestone rock from Saudi Arabia. Rock Mech Rock Eng 33:179-206. https ://doi.org/10.1007/s006030070006

Kuruppu MD, Obara Y, Ayatollahi MR, Chong KP, Funatsu T (2014) ISRM-suggested method for determining the mode i static fracture toughness using semi-circular bend specimen. In: Ulusay R (ed.) The ISRM suggested methods for rock characterization, testing and monitoring 2007-2014. Springer, 107-114

Lamarche J, Lavenu APC, Gauthier BDM, Guglielmi Y, Jayet O (2012) Relationships between fracture patterns, geodynamics and mechanical stratigraphy in Carbonates (South-East Basin, France). Tectonophysics 581:231-245. https://doi.org/10.1016/j. tecto.2012.06.042

Li B, Shen H, Qu S, Wang D, Liu C (2018) Tight carbonate reservoir characterization based on the modified rock physics model. J Appl Geophys 159:374-385. https://doi.org/10.1016/j.jappg eo.2018.09.012

Lian C, Zhuge Y, Beecham S (2011) The relationship between porosity and strength for porous concrete. Constr Build Mater 25:42944298. https://doi.org/10.1016/j.conbuildmat.2011.05.005

Lundborg N, Almgren LA (1972) Bestamning av brottseghet hos bergmaterial

Mavko G, Mukerji T, Dvorkin J (2009) The Rock Physics Handbook, Second. Cambridge University Press

Meille S, Lombardi M, Chevalier J, Montanaro L (2012) Mechanical properties of porous ceramics in compression: on the transition between elastic, brittle, and cellular behavior. J Eur 
Ceram Soc 32:3959-3967. https://doi.org/10.1016/j.jeurcerams oc.2012.05.006

Meredith PG (1989) Comparative fracture toughness testing of rocks. In: Mihashi H, Takahashi H, Wittman FH (eds) Fracture toughness and fracture energy: test methods for concrete and rock. Rotterdam, Brookfield, pp 265-278

Nath Singh R, Sun G (1990) A numerical and experimental investigation for determining fracture toughness of Welsh limestone. Mining Sci Technol 10:61-70. https://doi.org/10.1016/01679031(90)90850-R

Nemčok M, Gayer R, Miliorizos M (1995) Structural analysis of the inverted Bristol Channel Basin: implications for the geometry and timing of fracture porosity. Geol Soc, London, Special Publ 88:355-392. https://doi.org/10.1144/GSL.SP.1995.088.01.20

Ouchterlony F, Sun Z (1983) New Methods of Measuring Fracture Toughness on Rock Cores

Palchik V, Hatzor YH (2004) The influence of porosity on tensile and compressive strength of porous chalks. Rock Mech Rock Eng 37:331-341. https://doi.org/10.1007/s00603-003-0020-1

Paterson MS, Wong T (2005) Experimental rock deformation-the brittle field. Springer, Minerals and rocks

Peacock DCP, Sanderson DJ (1999) Deformation history and basincontrolling faults in the Mesozoic sedimentary rocks of the Somerset coast. Proc Geol Assoc. https://doi.org/10.1016/S0016 -7878(99)80005-4

Petit JP, Auzias V, Rawnsley KD, Rives T (2000) Development of joint sets in the vicinity of faults. In: Lehner FK, Urai JL (eds) Aspects of Tectonic Faulting. Springer-Verlag. https://doi. org/10.1007/978-3-642-59617-9

Rashid F, Glover PWJ, Lorinczi P, Hussein D, Lawrence JA (2017) Microstructural controls on reservoir quality in tight oil carbonate reservoir rocks. J Petrol Sci Eng 156:814-826. https://doi. org/10.1016/j.petrol.2017.06.056

Rawnsley KD, Peacock DCP, Rives T, Petit JP (1998) Joints in the Mesozoic sediments around the Bristol Channel Basin. J Struct Geol 20:1641-1661. https://doi.org/10.1016/S0191-8141(98)00070-4

Sabatakakis N, Koukis G, Tsiambaos G, Papanakli S (2008) Index properties and strength variation controlled by microstructure for sedimentary rocks. Eng Geol 97:80-90. https://doi.org/10.1016/j. enggeo.2007.12.004

Schaefer LN, Kendrick JE, Oommen T, Lavallee Y, Chigna G (2015) Geomechanical rock properties of a basaltic volcano. Front Earth Sci 3:1-15. https://doi.org/10.3389/feart.2015.00029

Schmidt RA (1976) Fracture-toughness testing of limestone. Exp Mech 16:161-167. https://doi.org/10.1007/BF02327993

Sheppard TH, Houghton RD, Swan ARH (2006) Bedding and pseudobedding in the Early Jurassic of Glamorgan: deposition and diagenesis of the Blue Lias in South Wales. Proc Geol Assoc 117:249-264. https://doi.org/10.1016/S0016-7878(06)80033-7

Sosa A, Espinoza DN, Frydman M, Barredo S, Cuervo S (2017) Analyzing a suitable elastic geomechanical model for Vaca Muerta Formation. J S Am Earth Sci 79:472-488. https://doi. org/10.1016/J.JSAMES.2017.09.011

Stoeckhert F, Brenne S, Molenda M, Alber M (2016) Mode I fracture toughness of rock under confining pressure. Eurock2016

Tucker ME (2001) Sedimentary petrology: an introduction to the origin of sedimnetary rocks

Tucker M, Wright V (2009) Carbonate Sedimentology. https://doi. org/10.1002/9781444314175

Vinciguerra S, Trovato C, Meredith PG, Benson PM (2005) Relating seismic velocities, thermal cracking and permeability in Mt. Etna and Iceland basalts. Int J Rock Mech Min Sci 42:900-910. https ://doi.org/10.1016/j.ijrmms.2005.05.022

Wang Z (2002) Seismic anisotropy in sedimentary rocks, part 1: a single plug laboratory method. Geophysics 67:1415-1422. https ://doi.org/10.1190/1.1512787

Zhang ZX (2002) An empirical relation between mode I fracture toughness and the tensile strength of rock. Int J Rock Mech Min Sci 39:401-406. https://doi.org/10.1016/S1365-1609(02)00032-1

Publisher's Note Springer Nature remains neutral with regard to jurisdictional claims in published maps and institutional affiliations. 